\title{
A Comparison between Traditional Chinese and Western Marriage Culture
}

\author{
Muqi Cheng \\ Beijing Language and Culture University, Beijing 100083, China \\ Email: maxinecheng2020@163.com
}

\begin{abstract}
Marriage is the most fundamental social institution in human society. Applying the comparative method, this paper aims at analyzing within the scope of marital and familial aspects of Chinese and Western culture, revealing specifically the underlying causes of the differences demonstrated in traditional Chinese and Western marriage culture. The paper finds that behind the apparent ritual practices, China and the West have different principles and priorities rooted in their ideological distinctions, namely, the differences in ethical foundations as well as family values. Chinese people, under the overwhelming influence of Confucian doctrines, regard parents as the sole authority in marriage, and ancestor worship has become the ultimate goal in the whole process, urging couples to conform to an extended family. In contrast, their western counterparts give priority to religious significance, and marriage is viewed as a divine unity of the two, which can be independent from large family relations thus forming a nuclear family of their own.
\end{abstract}

Keywords: marriage, ethical foundations, family values

\section{Introduction}

Marriage is considered the oldest and the most fundamental human institution. It is not only a milestone marking the new journey of one's life, but also the crucial element of civil society. Traditional Chinese and Western marriage culture share several similarities. For example, the presence of authoritative witnesses to the newlywed couple, and the influence of family of origin. However, contrasting the two marriage cultures manifests profound differences in ethical foundations as well as family values.

\subsection{A brief introduction to traditional chinese marriage}

Traditional Chinese marriage consists of a tedious process completed in Zhou Dynasty, namely, the "Three Letters and Six Etiquette", which is widely recognized as the foundation of marriage culture in ancient China.

The six wedding etiquette: (1) match making, (2) providing the date of birth and the birth hours, (3) marriage proposal and engagement, (4) sending the gifts, (5) picking auspicious wedding date, (6) the wedding ceremony.

The three letters: the Betrothal Letter, Gift Letter and Wedding Letter.

In ancient China, the marriage can be officially acknowledged only after finishing all these procedures.

\subsection{A brief introduction to traditional western marriage}

Practices of Western marriage is rather simple compared with that of Chinese marriage. The customs of western marriage can trace back to ancient Greece and Rome. The establishment of a traditional Western marriage basically includes making a proposal, engagement and wedding ceremony.

\section{Differences between traditional Chinese and Western marriage culture}

\subsection{Differences in ethical foundations}

Traditional Chinese and Western marriage differ in ethical foundations, with one being secular and the other being religious. In ancient times, Chinese feudal society was characterized by the strict control and suppression imposed by Confucianism, particularly the ethical standards and virtues proposed in the doctrine. Therefore, marriage inevitably demonstrates secular norms and moral obligations. In contrast, Christianity, as one of the foundations of Western civilization, has exerted profound religious influence on the formation of Westerners' social and spiritual life, and marriage culture is no exception.

Although both Chinese and Western marriages involve authoritative witnesses to the newlywed couple, the Chinese view their parents as authority, while westerners lay emphasis on the holy connection between men and God.

Under the ultimate influence of Confucianism, which advocates filial piety as a basic virtue, the famous Confucian 
philosopher Mencius vividly describes the features of ancient Chinese marriage: “父母之命，媒妁之言” (“Behests of parents and proposals of matchmaker"). Neither sons nor daughters can contract valid marriage without consulting their parents in advance, or they would be despised by other people. In other word, children are deprived of the freedom to choose their own spouse. "Behests of parents" clearly indicates that parents have the final say on the marriage of children, and under no circumstances can a child escape or ignore the duty of being completely obedient to them. Another request for newlywed couples associated with filial piety is parenting. Mencius also suggests that, “不孝有三，无后为大” (“Among the three forms of unfilial deeds, the most serious is to have no offspring"). Under the guidance of such doctrine, marriage and parenting was turned into a duty rather than a choice. It is worth noticing that till today, rituals as demonstration of filial piety are still retained in wedding ceremony. For instance, in the typical ceremony "bai gao tang", the newlyweds take an oath in front of their parents, as well as bowing down, kneeling and serving them tea, in order to show their reverence and appreciation.

In contrast, as a classic doctrine of Christianity, the Holy Bible plays an irreplaceable role in the development of western marriage culture. In Genesis, the religious significance of the first marriage of human beings can be perceived. God created Eve as Adam's helpmeet, and commanded that because she is a part taken out of Adam, the general rule of marriage should be that a man leaves his father and his mother, and cleaves unto his wife: and the two shall be one flesh (Bible, Gen. 2.2324). Westerners believe that it is God who has created marriage and presented this demonstration. Ryan claims that marriage is viewed as a "Sacrament", "In the broad sense we can understand it as referring to some event or some feature of human life which reveals God to man. The God whom the Bible tells us no man has ever seen or can see is somehow glimpsed in the midst of life" (Ryan, 555). It is widely believed among Westerners that a marriage can be formalized in a church setting, thus bonding a convenant between three. Therefore, the unity of their marriage and family can be strengthened, and eternal happiness can be realized with God's being present in them. Ryan believes that "what finds expression here is that in the exchange of human love there is the suggestion 'of something far more deeply interfused' -- of a divine love that is the origin of their love, and that carries and supports them" (555).

\subsection{Differences in family values}

Another distinction reveals in traditional Chinese and Western marriage culture is the value preference in family and social life. While the former values collectivism, the latter emphasizes individualism. The Chinese cling to an extended family and perform ancestor worship. On the contrary, Westerners attach more importance to individual life and keep aloof from relational system.

\subsubsection{Purpose of marriage: ancestor worship vs. unity of two}

According to Kiang, ancestor worship prevails in China, and it is constantly dominating people's cultural practice, including marriage.

"Every family must have a shrine with wooden tablets bearing inwriting the names of direct ancestors, and to them a sacrificial ceremony, however simple, is performed at least three times a year. Thus, ancestors are to their descendants the human gods; the head of every family is a primate, and all members in it, irrespective of sex or age, are subjected to this home service" (Kiang, 42).

His opinion is self-evident, since when tracing back to the earliest records of marriage in china, it can be observed that the purpose of marriage is elaborated in 《礼记·昏义》 (Marriage Propriety and Ceremony): “昏礼者, 将合二姓之 好，上以事宗庙，而下以继后世者也，故君子重之”(“The prime purpose of marriage is to worship the ancestors and make the clan prosper, by means of continuing the male offspring"). Ancient Chinese people believe that marriage is not just between the couple, rather it is a matter between two families. Furthermore, in this sentence, particularly the Chinese character "合” ("unity") carries deeper connotations with respect to ancestor worship. It indicates that for the sake of the whole family, parents and matchmaker must arrange marriages that are “门当户对” ("properly matched"). Only in this way can the prestige of their ancestors be guaranteed. Therefore, traditional marriage is less of a commitment made out of love and emotional attachment, but usually a measure to perform such solemn responsibilities endowed by a collective family.

In contrast, under the influence of Christianity, traditional Western marriages stress the convenant relationship and unity between the newlywed couples. Marriage thus can bring two mature believers together to better worship God. Interestingly, Richard Harries (qtd in Ryan, 1977) specifically addresses the worries brought by the solemnity of such a holy convenant. He notices "another fear, the fear of being submerged, of losing my freedom and individuality". Then he responds that "Christian faith suggests the reassuring model of a relationship where a profound unity is seen to enhance rather than threaten one's own personal uniqueness", Husband and wife "become one but with no loss of individuality" (Harries). All these demonstrate the significance of individuality in Western marriage. 


\subsubsection{Extended family vs. nuclear family}

The engagement level of family of origin in married life is extremely different in traditional Chinese and Western marriage culture. While Chinese people usually live in an extended family, a nuclear family is more valued for westerners.

Kiang offers his interpretation of the extended family in China:

"The Chinese written character for family is the pictorial representation of three persons under one roof, meaning possibly man, wife, and child. But, according to Chinese etymology, 'Three persons make a crowd,' so it is by no means to be literally limited to the number three" (Kiang, 40).

It is true that a traditional Chinese family always consists of many more members

than a Western family, thus developing more complicated family relationships. As for the newlywed couple, responsibilities come along when the bride officially becomes daughter-in-law after marriage. She must integrate into her husband's family and properly deal with numerous family relationships. For instance, she needs to get on well with the husband's parents and relatives of his side. Moreover, the crucial role in a traditional extended family, the Chia-Chang, usually a male, should be the head of the family and also elder of the family. Su specifically takes a Chia-Chang's authority of household financial control as an example, which also manifests the collective family values in ancient China. "As executive and financial head of the family, he has the right to compel all members to turn their earnings into the common purse to be used for the current expenses of the whole family" ( $\mathrm{Su}, 18)$. Also, "he must care for and disburse the funds in a way that will ensure the support and maintenance of the whole family" (18). And the others will submit to his administrative power. Therefore, "the family, in fact, is a corporation and the Chia-chang is its manager" $(\mathrm{Su}, 18)$.

Contrarily, in western tradition, nuclear family proves people's inclination to stand aloof from relation systems, and retreat from a wider society. As suggested by B.Harrison and J.Harrison, marriage is treated as "an isolated relational system, one that can thrive and sustain itself without broader nurturing and validating networks of relationship" (76). Westerners has a "tendency to turn inward, to experience interpersonal intimacy as an end in itself without regard to other human relations" (76). Consequently, the nuclear family type also implies that people are becoming increasingly "incapable of community" (B.Harrison and J.Harrison 75) after marriage.

\section{Conclusion}

Examining traditional Chinese and Western marriage customs allows people to gain insight into the differences in ethical foundations and family values between both cultures. Though Chinese and Western marriage cultures are characterized by colorful diversities, there is still harmony existed in them, since the eternal pursuit of happiness and continuation of life is shared by all.

\section{References}

[1] Harrison Beverly, Harrison James. Some Problems For Normative Christian Family Ethics. The Annual Meeting. 1977: $72-87$.

[2] Kiang Kanghu. The Chinese Family System. The Annals of the American Academy of Political and Social Science. 1930; 152: 39-46.

[3] Dai Sheng. Marriage Propriety and Ceremony. In: Book of Rites.

[4] Mencius. Li Lou part one. In: The Book of Mencius.

[5] Mencius. Teng Weng Kung part two. In: The Book of Mencius.

[6] Ryan Seamus. Spirituality and Christian Marriage. The Furrow. 1977; 28(9): 554-567.

[7] Su Singging. The Chinese Family System. Philippine Sociological Review. 1954; 2(3): 17-26.

[8] China Christian Council. Gen. 2: 23-24. In: The Holy Bible. China Christian Council; 1996. 